\title{
The 60s of the 20th Century: Modern Movement Public Catering Buildings in Latvia
}

\author{
Luīze Marta Aizpurva, Riga Technical University, Riga, Latvia
}

\begin{abstract}
The study summarizes information on buildings of catering establishments of the $1960 \mathrm{~s}$ in Latvia. The analysis of the interior, exterior, location of the buildings as well as the possibilities for their restoration has been carried out. Information on the restoration and preservation of the Modern Movement architecture in the world has been analysed as well.
\end{abstract}

Keywords - Latvia, Modern Movement, public catering buildings.

\section{INTRODUCTION}

The 1960s were characterized by search of new architectural forms. The ideas and stylistic traits of functionalism of the first quarter of the twentieth century fundamentally dominated, yet increasingly experiments with a variety of new materials and shapes took place. Although Latvia was part of the Soviet Union at that time and was largely isolated from the cultural, artistic and architectural current of the Western world, the main features of the Modern Movement were found in the region. Architecture of the Modern Movement of the sixties is only gradually identified as being of protection value in Latvia. For a long time, it was seen as a worthless, unpleasant surplus of the Soviet Union without going into the architecture itself. This is why many objects of its time have been degraded, rebuilt or completely destroyed. As long as the objects that can be restored remain, it is possible to perform the analysis and to develop conservation guidelines. Research work analyses nine catering institutions of the sixties of the 20th century Modern Movement in Latvia: restaurants Pilskalns, Sēnīte, Piena restorāns, Vārava, Jüras pērle, cafés Rèzna, Klidzinga, Priedes, and cafeteria Baltija.

\section{Architecture of the Modern} Movement of the 1960s in Latvia

"Modern Movement following World War II was a post-modern sequel to pre-war Modern Movement, or functionalism" [13, 115]. It was implemented in a rationally simple artistic finish of buildings without any ornamental decoration. The shape of the buildings is dominated by highly horizontal divisions, with flat roofs hidden behind the parapets. It is characterized by simple geometrical shapes." $[3,165]$. Often, buildings were built with expressive cantilevers that create an impression of futuristic "flying architecture". If outwardly Modern Movement buildings are laconic and relatively monochrome, then the interiors are most frequently oversaturated with expressive paintings, textures, bright accents and art objects. This section summarizes the visual and technical state of each analysed building today.

Restaurant Pilskalns (Castle Mound) by architects Edgar and Aina Šēnbergs is located in Bauska. The building was completed in 1962. Located in a strategically beneficial place - near the Bauska Castle on the way to Rundāle Palace, it attracted hundreds of people every day. When the political and economic situation in the country changed, the once popular place lost its popularity. When the restaurant ceased to exist, a nightclub was opened in the building. The former restaurant's household building has already been rebuilt as a café and is still functioning. In 2014, Bauska local media announced that it is planned to renovate and re-open the former restaurant building. The building was still undergoing repairs in 2018. Over time, it has experienced a variety of transformations, and only the main structure of the original project has remained.

Restaurant Sēnīte(Mushroom) in Inčukalns parish, near Vidzeme highway, is a unique example of the architecture of Modern Movement (Fig. 1). The main hall of the former restaurant has a roof that is the first concrete shell construction in Latvia. The authors of the project are architect Linards Skuja and engineer Andris Bite. The restaurant was opened for visitors in 1967, and for many years was one of the most famous restaurants in the Soviet Union. The restaurant hosted the filming of one of the most popular Soviet movie comedies "Diamond Hand", with the well-known Russian film actors Yuri Nikulin and Andrei Mironov. Also famous French comedian Louis de Finess had stopped for a meal here on the way back from the film festival in Sweden [9]. Although Sēnite has been granted the status of an architectural monument (2016), the complex has been degraded, structure has lost some parts of the original building, and some disproportional annexes have been added in later years.

The former Piena restorāns (Milk Restaurant) at Kronvalda Park in Riga (later café Ainava (Landscape) has been transformed completely. In 1969, a café designed by Joseph Goldenberg, was rebuilt as an office building for the Riga Free Port Authority. There is nothing left of the original apropos park-size building. As a weak reference to the former café building an outdoor terrace and glazing on the front towards the canal has also been set up for the new office building.

Nowadays restaurant Värava (Mermaid) in Saulkrasti is a demolished slum. It is difficult to realize that it has ever been completed and used. Only the main structure has remained. The author of the restaurant is architect Harijs Pētersons. It was built in 1969. Local residents and Saulkrasti resort holidaymakers from all over the USSR attended the restaurant. In 1980, because of the Moscow Olympics (the Olympic Regatta was held in Tallinn) Vărava, as one of the main stopping points on the route Tallinn-Salacgrīva-Riga, was repaired. After the collapse of the Soviet Union, Vârava was less and less visited until the restaurant was closed in 1994. Since then, it has stood abandoned and is rapidly degrading further. 


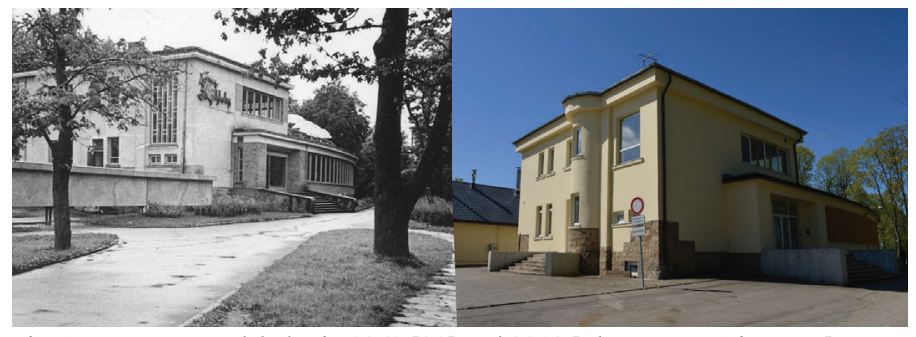

Fig. 1. Restaurant Pilskalns in 1960 [20] and 2018 [Photo: L.M.Aizpurva].

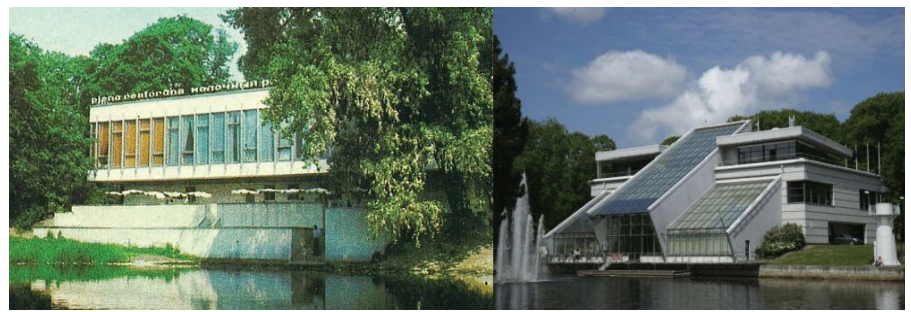

Fig. 3. Piena restorāns in 1970 [12] and 2017 [14].

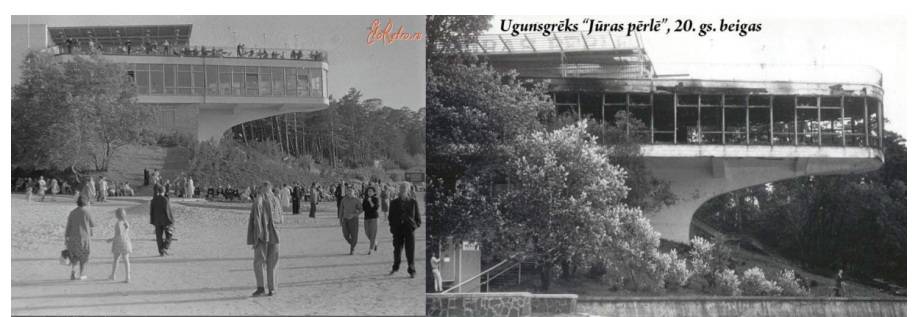

Fig. 5. Restaurant Jūras Pērle in 1969 and in 1991 [18].

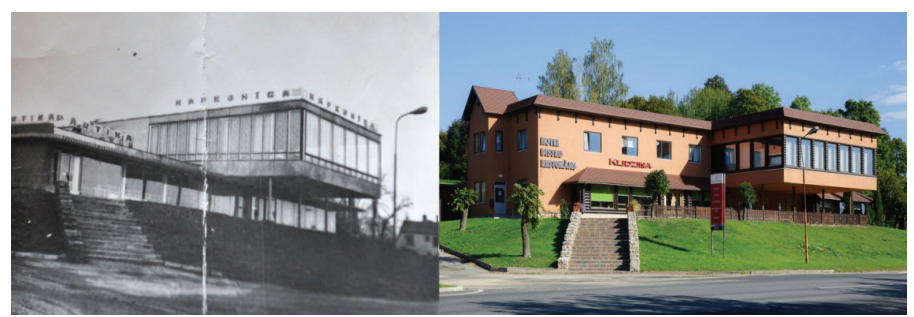

Fig. 7. Café Klidzinga in 1960 and 2016 [17].

Restaurant Jüras pērle (The Sea Pearl) - a visually impressive restaurant in Jürmala was an exclusive place for holidaymakers from all over the USSR. As Jürmala was one of the main sea resorts of the USSR, it was a particularly exclusive place. In 1964, the restaurant was built on the seashore to the project of architect Joseph Goldenberg; the building impressively stood out over the beach. Jüras pèrle was known not only for its expressive architecture, but also for its music and dance show program. The restaurant lost its popularity when the Soviet Union collapsed and the number of restaurant visitors fell sharply. In 1991, a fire occurred in the building. The fire damaged the building repeatedly, until in 2001 the building, destroyed by fires and vandals, was demolished entirely.

Café Rēzna was constructed in 1968, in Rēzekne city centre. The architects of the building are Jānis Krastiņš and Juris Pētersons.

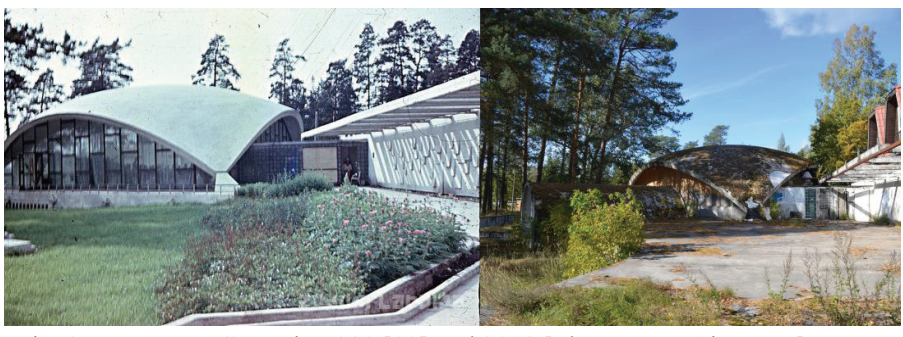

Fig. 2. Restaurant Sēnīte in 1980 [10] and 2018 [Photo: L.M.Aizpurva].

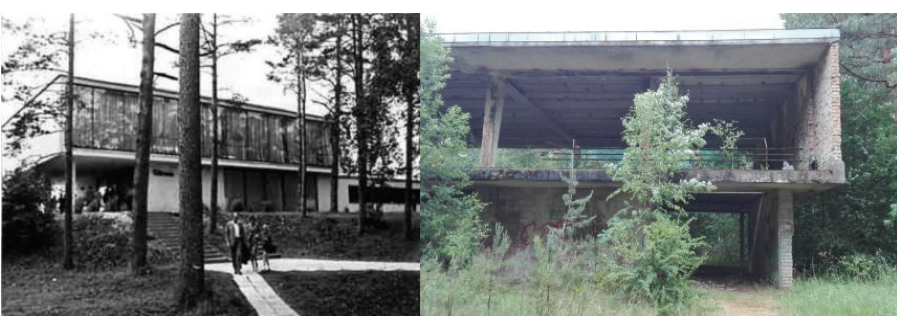

Fig. 4. RestaurantVārava in 1975 [15] and 2018 [Photo: L.M.Aizpurva].

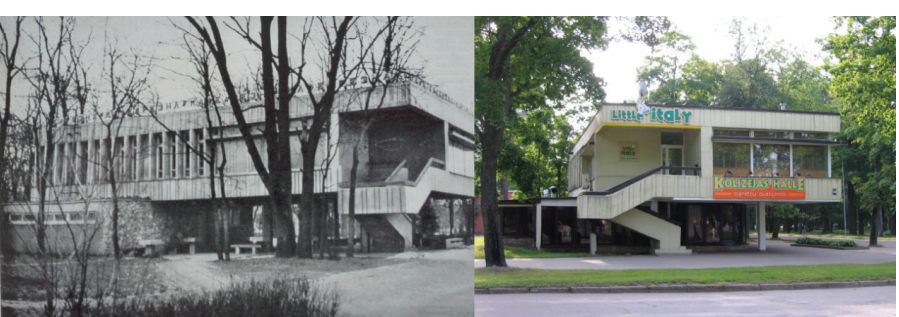

Fig. 6. Café Rēzna in 1968 [3] and 2014 [Photo: L.M.Aizpurva].

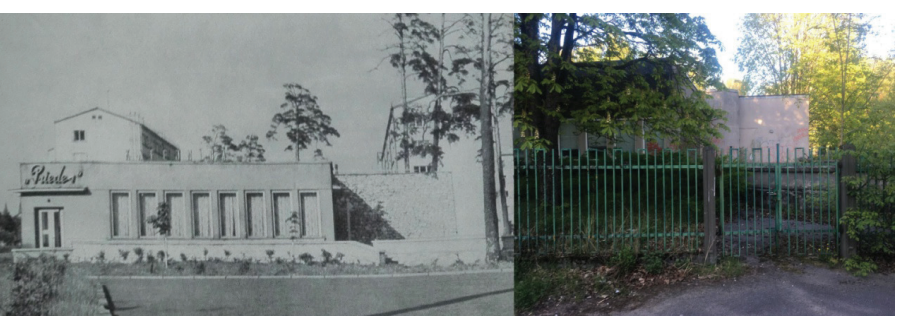

Fig. 8. Café Priedes in 1960 [1] and 2018 [Photo: L.M.Aizpurva].

Perhaps, because of its compact size the building has not experienced the fate of restaurants Vārava or Jüras pérle. Even after the collapse of the USSR this building was economic enough to be maintained and managed without the finances of the former powerhouse. The building is in a visually good technical condition and currently functions as a restaurant, bar and games room. This small-scale building has survived externally without rebuilding. The biggest change in external shape is the extension of the ground floor by building the vacant area below the first floor of the building. The original interior has not been preserved.

Café Klidziņa was designed by architect Edgars Šēnbergs. It was built in 1960. Klidzing has experienced the same process of degradation as Värava and Jüras pērle - right after the collapse of the USSR, the once popular café declined. "From the 1990s to 2001, no economic activity was carried out and the premises were empty. Kliga Lat SIA restored only the café, but the busi- 
ness had not been successful and the facility was sold in early 2011. The building was in poor condition; renovation was done of existing spaces and a second floor in which the hotel is located". [16] During the refurbishment of the café the original style of the building has not been observed. The new annex completely breaks down the size of the original building. Only part of the basic shape of the Modern Movement building has been preserved.

The building of former café Priedes (Pines) in Ägenskalns was completely rebuilt several years ago. Originally the café was designed by architect Gunta Irbīte. The café was built in a new housing complex of Āgenskalna priedes (Pines of Āgenskalns) as one of the public buildings of the complex. The building has now been rebuilt and degraded. It is planned to completely demolish the former café and to build a new multi-apartment residential building instead.

The two-story cafeteria Baltija in Ägenskalns, at Melnsila iela 22 was designed by architect Māris Gundars, but Aleksandrs Stankevičs was responsible for wall paintings on the premises [11]. The building is now completely rebuilt and contains a pizzeria as well as several shops. The second story volume with fenestration of the original shape has been preserved. The original shape of the building is changed by the new annex to the ground floor and the monochrome finishing of the facade.

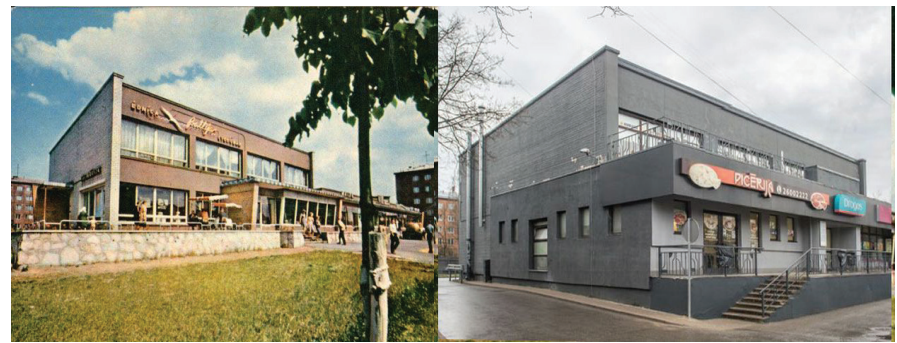

Fig. 9. Canteen Baltija in 1962 and 2018 [17].

\section{Analysis of the Modern Movement Catering Services Buildings of the 1960s}

The building analysis examined three aspects: 1) the location of the site in the environment and spatial planning, 2) the size and shape of buildings, as well as 3) the interior.

By location, the sites selected in the research study may be divided into four groups with each group having its own specific characteristics.

1. The object is located in a large-scale residential complex (café Priedes, cafeteria Baltija). The location of these buildings is determined by overall layout of the complex.

2. The site is located on the sea-coast in the dune zone (restaurants Värava and Jüras Pērle). These buildings are unique due to the fact that it is not possible to build such large buildings in the dune area anymore. The Protection Zone Law defines the following criteria:“... the protection zone for shore dunes, the width of which depends on the width of the dunes zone, but not less than 300 meters in the land direction, counting from the place where natural terrestrial vegetation begins [...]" [8].
3. The facility is on the side of the road outside the city (restaurant Sènite, café Klidziña). These objects are marketed to the flows of the long-distance drivers and tourists. Objects are located away from the city borders at the very edge of the road, with spacious parking lots.

4. The facility is located in or close to the city centre (café $R \bar{e} z$ $n a$, restaurants Piena restorāns and Pilskalns). Catering facilities for urban residents and guests in a convenient and well-known place are the most common group. It includes both cafés and canteens, and restaurants, for a variety of situations and price ranges. The features of Modern Movement appear most prominently in the shape of buildings. In order to better understand its manifestations in Latvia, as well as the different regional characteristics, the external structure of buildings, materiality, as well as functional planning was analysed. Each of the buildings is dedicated to its visual image and its various unique technical solutions. All buildings show the hallmarks and influences from the world's most famous architects of the Modern Movement - Eero Saarinen, Oscar Niemeyer, Mies van der Rohe, and Le Corbusier. Le Corbusier and Mies van der Rohe's geometrically clean, laconic-shaped aesthetics mostly dominate. Rstaurant Sēnìte reflects more specific analogues of the Modern Movement, the typical shell shape of Eero Saarinen, and the shapes of the Oscar Niemeyer Palácio do Planalto building (Fig. 10). Interesting discovery in the course of the study is that part of the main structure of restaurant Pilskalns is a pre-war functionalism residential building. It is an interesting example in which architects successfully connected the buildings of Modern Movement of two different times into a single building.

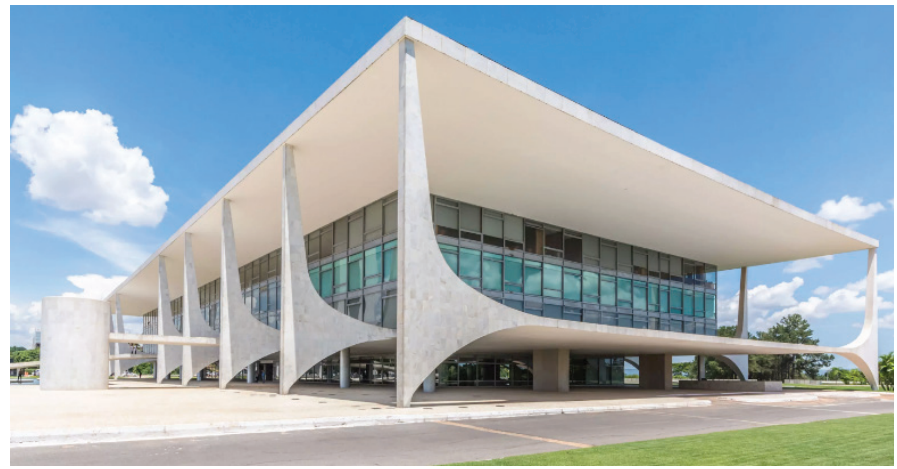

Fig. 10. Palácio do Planalto [19].

In general, the buildings are characterised by monochrome facades, concrete panels in front finishing, large glazings and expressed horizontality. The space planning shows a considered division between functional zones. Regional features appear more prominently in the selection of building materials and technical solutions.

The hallmark of the interiors of the Latvian Modern Movement catering establishments is the saturation of the premises with bright colours and art objects. The information on this topic is limited, so more objective assessment was also carried out of other Modern Movement catering establishments of the 1960s, not just those listed in the list of sites. Publications were also ana- 
lysed on interior solutions in residential buildings and other public institutions, as the stylistic forms and materials of the Modern Movement in public institutions and residential buildings are similar. On the principles of building public spaces, Ivars Strautmanis wrote a lot at the time. "A man in public spaces looks not only for a certain purpose or progress fulfilment, he unwittingly aims to experience something uncommon, uplifting. [...] When you use the name "catharsis" so popular in the art of the stage, we can say that a properly designed and well-disposed interior of spaces, both with its functional solution and emotional feel, the occurrence of such cathartic moments should be encouraged. [...] In fact, there is also a reason why architects are increasingly (and more purposefully) seeking to involve representatives of different arts." $[6,17,18]$. The synthesis of architecture and arts can be observed in almost all of the objects analysed. There is a great difference between the interior of the buildings and the exteriorunlike monochrome facades, the interiors were designed bright and saturated with details.

A particularly creative approach was in the design of wall decorations and bulkheads. The walls were adorned with wood-carvings, ceramics, tapestries, murals, stained-glass, and also bright colours. Similarly, it is common to divide the room into non-performing areas by tapestries, draperies, sculptural objects, flower boxes, and metal grille structures. No lesser care and creativity is devoted to the ceiling finishing and lighting fixtures than to wall-finishing. The furniture design is more approximated to the styling of building facades - in geometrical and laconic shapes. In furniture of the second half of the 60 s decorative elements are rarely used, infinitely less than in the furniture of the late 50s. The most common type of adornment is the finisher of the facade with the doused veneer of the pickling tree, as opposed to the hard wood-framed furniture housing. A different finish was also used - for example, polished facades, but casings were simply lacquered. Such furniture started to appear in which part or all of the visible surfaces were coated with polyester varnish and polished brightly $[4,156]$. A major role was attributed to indoor-outdoor merging using not only extensive glazing but also by creating green zones indoors. Palms, rubbery trees, ferns, cactus, alleys and other kind of plants were placed in the rooms. In the interior of cafeteria Baltija, for the first time in the Latvian SSR, a rock garden with a pool and exotic plants was created [2, 22]. Great attention also was given to outdoor green area, for example the public buildings' entrance area was frequently decorated with flower boxes. Public spaces were designed wide and lightmaximizing the use of natural daylight.

\section{Preservation and Restoration of the Modern Movement Architecture of the 1960s.}

By analysing foreign sources of information, it can be concluded that the idea of preservation of the architecture of the Modern Movement of the sixties is also topical elsewhere in the world. But, like in Latvia, it is not such a simple and easy-to-resolve issue. Firstly, these buildings are built without taking into account the energy efficiency and sustainability of buildings, which is currently one of the main factors in building construction. Secondly, many of these buildings, in terms of the size of the premises, are larger than necessary for the performance of certain functions today, which makes it difficult to find owners and application for them.

In the context of the restoration and preservation of the Modern Movement architecture, two large organizations - DoCoMoMo and "The Getty Conservation Institute" - play an important role. DoCoMoMo deals with a survey of the architecture of Modern Movement around the world. The objectives of the organization are to safeguard the legacy of the Modern Movement, if threatened; to accumulate ideas, solutions and views on technologies for the preservation of buildings in the Modern Movement, and to organize conservation training; to gather information on the Modern Movement; to bring public responsibility to this heritage [7]. The Getty Conservation Institute is an architectural conservation institute that collects information, develops guidelines and organizes practice sessions in relation to the renovation and restoration of buildings. A few years ago, the Institute also addressed the issue of the renovation of the buildings of the Modern Movement. The Getty Conservation Institute has published publications on the preservation of the concrete heritage, as well as a bibliography with examples of the preservation of the legacy of the twentieth century ("Conserving Twentieth-Century Built Heritage: A Bibliography"), for quality preservation of the Modern Movement architecture and in practice.

By renovating some of the catering establishments of the Modern Movement of the 1960s it must be defined whether the building is to be reconstructed or renovated, preserving its visual image. It is necessary to understand the purpose of the renovation: to leave only a visual example with the architecture of a given period or, however, to be an original monument of its time. It is also necessary to take into account today's rules, which do not correspond to the parameters that have been established earlier. This is the most common reason for the transformation of historic buildings that have not been granted the status of an architectural monument.

In general, older buildings tend to be renovated with original materials (or using as close as possible modern solutions), but with buildings of the sixties it is different. In parallel to steel, concrete and glass, the architects of the Modern Movement also worked with other new materials, such as lead, lead paint and asbestos, which are today judged to be hazardous to health and the environment. As a result, due to their toxicity, low energy efficiency and material wear, materials used during Modern Movement in restoration activities should often be replaced. Their replacement should be carefully considered and the solution should be as gentle as possible against the authenticity of the original structures and materials $[5,20]$. The quality of the construction was relatively low, and it should be assessed which alternative solutions of the time should be counted under the "own-time label" (e.g. cinema Kosmos in Estonia, in the case of facade dressing [5, 103]), and which solutions must nevertheless be counted as poor-quality construction and corrected when restoring or renovating the building. 
Architects operating in the territory of the USSR, including Latvia, have been actively trying to follow the world's current trends, often without considering how the specific trends and solutions would work under different climatic conditions. Similarly, in the context of Latvia, there could be a problem with matching materials directly for restoration purposes. Many of the materials produced in the sixties, even in the 1980 s, are no longer produced. Nor do people consider the various products of this time to be of value, and they are discarded during the repair of their homes, so many of the evidence of this time has not remained.

\section{Conclusions}

In the 1960s, the architects working in the USSR and Latvia had a noticeable impact from the examples of the Modern Movement elsewhere in the world. However, in the former territory of the USSR, the architecture of the Modern Movement of the sixties differs from the rest of the world; due to a lack of materials, architects have sought original technical solutions that are not observed in other countries. The interiors have a saturation of colours and details, while the facades are laconic and monochrome.

The issue of preserving and restoring the architecture heritage of the Modern Movement of the 1960s is topical, but relatively new also for the rest of the world. It is only gradually that realistic, experimental examples of renovation are emerging. The choice of renovation and restoration methodologies and materials to be used depends on the status of the site, the existing technical state, the original project and other related sources of information. Ensuring the energy efficiency and environmental accessibility of buildings can pose major challenges in the restoration process.

Most frequently quality of the construction of the Modern Movement buildings of the sixties was relatively low. In restoration process, poor quality construction should be replaced with an appropriate, high-quality solution and some materials should often be replaced by appropriate analogue. Also, few of the existing buildings of this period, particularly the interiors, still have the original elements and they could be used in restoration process.

\section{REFERENCES}

1. Apsītis, V., Driba, I., Šusts, V., Tītmane, A., Zakamennijs, O. Laikmetīgā arhitektūra padomju Latvijā. Rīga: Izdevniecība Liesma, 1966. 98 lpp.

2. Driba, Dz. Interjers iepriecina. Māksla, 1962, Nr. 2 (14), 21.-23. lpp.

3. Dripe, J., Krastinš J., Strautmanis, I. Latvijas arhitektūra no senatnes lùdz mūsdienām. Rīga: Baltika, 1998. 312 lpp. ISBN 9984-9178-3-5

4. Emsiñš, J. Koks Latvijas valsts un tautas dzīivè. Jelgava: Studentu biedrība "Šalkone", 2014. 202 lpp. ISBN 978-9984-48-166-1

5. Estonian Cultural Heritage. Preservation and conservation. 2013-2017. Tallin: Tallinna Raamatutrükikoja, 2017. 161 p. ISSN 2228-4877

6. Strautmanis, I. Dialogs ar telpu. Rīga: Liesma, 1982. 136 lpp.

7. About. Mission [online]. Docomomo [cited 11.09.2018]. https://www.docomomo.com/about/organization/

8. Aizsargjoslu likums [online, cited 08.05.2018]. https://likumi.lv/doc. php?id= 42348

9. Dzedulis, Z Z Vai ataugs jauna "Sēnīte"? Nostaḷ̂giskas piezīmes un "Liepkalnu” superplāns [online]. LA.LV : Zinuu portāls Latvijai [cited 11.09.2018]. http://www.la.lv/vai-ataugs-jauna-senite/

10. Inčukalna pagasts. Restorāns "Sēnīte" [online]. zudusilatvija.lv [cited 11.09.2018]. http://www.zudusilatvija.lv/objects/object/37482/
11. Jākobsons, E. Aizgājušo gadu šarms : Padomju modernisma interjeri, 24.04.2017 [online]. Laikmeta Zìmes [cited 10.05.2018]. http://www.laikmetazimes.lv/2017/04/24/aizgajuso-gadu-sarms-padomju-modernismainterjeri/

12. Jākobsons, E. Padomju arhitektūras mantojums Latvijā. Padomju modernisms, 1960-1970, 18.04.2016 [online]. Laikmeta Zīmes [cited 08.05.2018]. http://www.laikmetazimes.lv/2016/04/18/padomju-arhitekturas-mantojums-latvija-padomju-modernisms-1960-0E2\%80\%93-1975/

13. Krastiṇšs, J., Arhitektūras stili Latvijā [online]. mantojums.lv [cited 08.05.2018]. http://mantojums.lv/media/uploads/dokumenti/petijumi/arhitekturas_stili_latvija.pdf

14. Rīgas Brīvostas pārvaldes ēkas pārbūve [online, cited 11.09.2018]. http://skontobuve.lv/lv/objekti/rekonstrukcija-un-restauracija/rigas-brivostas-parvaldes-ekas-parbuve

15. Saulkrasti. Restorāns "Vārava" [online]. zudusilatvija.lv [cited 11.09.2018]. http://www.zudusilatvija.lv/objects/object/31326/

16. Stepina, K. Skrīverus atkal rotā „Klidzina” [online]. Dienas Bizness, 17.08.2006 [cited 10.05.2018]. http://www.db.lv/zinas/foto-skriverus-atkal-rota-klidzina-452953

17. Toreiz un tagad. Ëdnīca «Baltija» Rīgā, Melnsila ielā 22 [online]. tvnet. lv [cited 18.09.2018]. https://www.tvnet.lv/4527837/toreiz-un-tagad-ednica-baltija-riga-melnsila-iela-22

18. Unikāli foto: prestižais padomju restorāns Jūras pērle. No greznības līdz postam [online]. skaties.lv [cited 16.10.2018]. https://skaties.lv/izklaide/ raibumi/unikali-foto-prestizais-padomju-restorans-juras-perle-no-greznibas-lidz-postam/

19. Viramonte, G. Oscar Niemeyer Palácio do Planalto, 1960 [online, cited 11.09.2018]. https://divisare.com/projects/308171-oscar-niemeyer-gonzalo-viramonte-palacio-do-planalto-1960

20. Zvirgzdiñ̌s, A. Edgars Šēnbergs. Aizmirstais modernisms [online]. A4d.lv [cited 14.05.2018]. https://a4d.lv/raksti/edgars-senbergs-aizmirstais-modernisms/

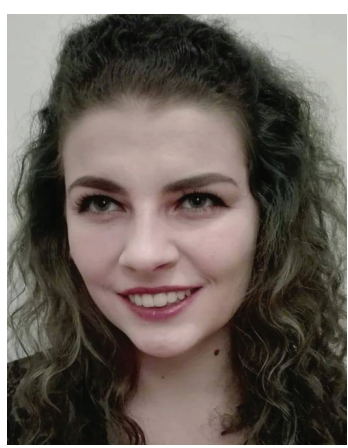

Luīze Marta Aizpurva has acquired the professional Master's degree in Architecture and Architect qualifications in 2019 from Riga Technical University. Since 2017, she has been employed by Arhitektoniskās izpētes grupa' dealing with exploration of historic buildings as well as the development of projects for conservation and renovation of the buildings. Her main research interests are identification and preservation of the architecture of post-war modernism in Latvia, as well as the successful adaptation of historic buildings to modern requirements, keeping them as close as possible to their historical form.

Luīze has participated in the 58th Riga Technical University Students' Scientific Conference with her Bachelor's work "Light in Urban Latvia". She won the Professor Ivars Strautmanis' Latvian Regional Architecture Prize in 2018 for her Master's Thesis “The 20th Century's 1960s Modern Movement Public Catering Buildings in Latvia. Opportunities for the Restoration of the "Pilskalns" Restaurant."

\section{Contact Data}

Luīze Marta Aizpurva

E-mail : 1maizpurva@inbox.lv

Phone. +37126378282 